\title{
Progress in Understanding and Treating Parkinson's Disease
}

\author{
ANDRÉ BARBEAU
}

\begin{abstract}
SUMMARY: This review evaluates the long-term results of Levodopa therapy in Parkinson's disease upon quality of life, prolongation of survival and excess mortality. It also focuses on recent and new therapeutic approaches: Levodopa in combindation with a Dopa-decarboxylase inhibitor or MAO-B inhibitor, dopamine agonists and an active tripeptide: L-prolyl-L-leucylglycine amide (MIF-I). It ends by looking at new avenues of etiological research in Parkinson's disease which may indicate specific accelerated ageing of catecholaminergic (pigmented) neuronal systems.
\end{abstract}

RESUMÉ: La présente revue évalue les résultats à long terme avec la Lévodopa dans la maladie de Parkinson et ses effets sur la qualité de la vie, l'augmentation de la durée de survie et le taux excessif de mortalité préalablement noté. Il est aussi fait mention de nouvelles approches thérapeutiques: Lévodopa combinée à un inhibiteur périphérique de la Dopa-decarboxylase ou un inhibiteur de la MAO-B, agonistes de la dopamine et un tripeptide avec action $M I F$, le L-prolyl-L-leucyl-glycine amide. En conclusion de nouvelles avenues de recherches étiologiques sont mentionnées qui semblent indiquer qu'il existe dans la maladie de Parkinson un vieillissement accéléré spécifique des systèmes neuronaux catécholaminergiques (pigmentés).

From the Department of Neurobiology, Clinical Research Institute of Montreal.

Reprint requests to: Dr. André Barbeau, Clinical Research Institute of Montreal, 110 Pine Avenue West, Montreal, Quebec, Canada.
Research in Parkinson's disease has been extremely productive within the last 20 years as a result of the impetus given successively by the advent of stereotaxic surgery and later of Levodopa. A number of publications and monographs should be consulted for understanding the background discoveries until 1975 (Barbeau and McDowell, 1970; Yahr, 1973; Calne, 1973; De Ajuriaguerra, 1971; McDowell and Barbeau, 1974; Calne et al., 1975). It would be impossible, because of space limitations, to review all the basic developments underlying and justifying the recent clinicotherapeutic advances. Many original findings based on newly developed fluorescence histochemical techniques as well as electrophysiologic and iontophoretic methods have revolutionized our understanding of the role of catecholamines in the brain (Blashko and Muschall, 1972). For example, we now know of at least four important dopaminergic pathways in the central nervous system: a nigro-striatal pathway, a mesolimbic pathway, an infundibulo-hypothalamic pathway and, more recently, a cortical dopaminergic system (Fuxe, 1970; Thierry et al., 1975). We now understand better the central role of the locus coeruleus as the head center for almost all noradrenergic pathways irradiating to all parts of the brain, including the cerebellum (Divett, 1973). Moreover a new independent "islandic" catecholaminergic system has been identified within the striatum, whose function is still not completely understood (Fuxe, Unpublished observations). Dopamine receptors, formerly thought to be entirely post-synaptic in location, can also be found pre- synaptically and even upon the cell bodies, leading to the use of the new term auto-receptors. Each one of these developing concepts bears upon the understanding of the longterm effects and complications of Levodopa therapy.

Introduced in 1961 (Barbeau, 1961; Birkmayer and Hornykiewicz, 1961), the Levodopa replacement approach became therapeutically useful when Cotzias and collaborators, in 1967, considerably increased the daily dosage. It has now been nearly 9 years since this regimen was initiated and a number of long-term evaluations have recently appeared (Barbeau, 1969, 1975a, b, 1976; Markham et al., 1974). It is interesting to note that every author clearly states that Levodopa is still, after all these years, the best therapeutic approach available in Parkinson's disease. There is no question that it considerably enhances the quality of life for the surviving years. However some controversy still exists regarding the effect of long-term Levodopa therapy upon prolongation of life and mortality. This controversy is based on the appalling lack of exact information concerning the natural history of Parkinson's disease in the years preceding Levodopa therapy. Only a few studies of any merit exist and most lack some important data (Hoehn and Yahr, 1967). Because of this situation statistical comparisons of pre and post-Levodopa periods is difficult, if not impossible. Nevertheless, it now appears that Levodopa does not prolong the survival of severely akinetic patients (Barbeau, 1976) but, if new data from Markham et al. (1974) and Yahr et al. (unpublished, 1975) are to be believed, it has contributed to 
extending the life of less severely affected patients. For example, their evidence places the average age at death of these patients at 73 , from a previous 65.9. This new figure is close to the average age at death of a control population. More important still, Levodopa would appear to decrease significantly the increased mortality previously observed with Parkinson's disease. This figure had been estimated at 3.0 and 1.5 times the expected mortality rates of control populations by Hoehn and Yahr (1967). It now apparently stands at 1.5 and 1.0 respectively in Yahr (1975) and Markham's (1974) material. Most of this gain, however, is by reducing the early deaths in the first few years of treatment. This development is most important and, if confirmed by others, could indicate that a decreased striatal dopamine does contribute to cell ageing phenomena (Barbeau, 1973), and if it is corrected early enough, that one could arrest the inexorable progress of specific "accelerated" cell death in Parkinson's disease. Once the cells have disappeared, as they probably have in the severe cases, dopamine replacement, while effective on motility, cannot alter the cell death process. It will be extremely important, in the next few years, to follow these developments, since they bear upon the crucial process of ageing.

Some of the long-term problems encountered with Levodopa: abnormal involuntary movements, and oscillations in performance, have already been described in detail and correlated to the supersensitivity of dopamine receptors and the effective plasma DOPA levels (McDowell and Barbeau, 1974; Calne et al., 1975). Little new data has been added concerning the pathophysiology of these still disturbing occurrences. It is now recognized, however, that one of the main disabling symptoms of advancing Parkinsonism is a progressive gait disturbance which combines features of "start hesitation", and cerebellar damage. The analysis of this phenomenon has led to the recognition of four types of "akinesia": (1) akinesia secondary to rigidity, which still responds best to stereotaxic surgery and, partially only, to Levodopa; (2) akinesia secondary to striatal dopamine deficiency: this is the ideal indication for Levodopa therapy; (3) "akinesia paradoxica", of paroxystic hypotonic freezing, a progressively more frequent impairment thought to be due to evolving central noradrenergic pathway damage and occasionally made worse by Levodopa; (4) finally a "pure akinesia syndroine" masquerading as Parkinsonism, which appears to include cerebellar involvement and does not respond to Levodopa (Barbeau, 1975a, b; Marsden and Parkes, 1976).

In an attempt to break through these emerging therapeutic barriers, and relieve the various forms of akinesia, oscillations in performance and dyskinesias, a number of new approaches have recently been proposed. The first of these, which has now reached the level of a marketable drug after 6 years of experimental study, is the combined treatment with Levodopa and a peripheral Dopa-decarboxylase inhibitor (Birkmayer and Mentasti, 1967). This has permitted, as is now well known, a marked decrease in the peripheral side-effects of nausea, vomiting and cardiac arrythmia, possibly at the expense of earlier and slightly more severe dyskinesias. In our experience, this combined treatment is much to be preferred to the standard Levodopa high level therapy. However, it has not appreciably modified the central neurological side effects previously observed (Barbeau and Roy, 1976).

Because it was thought that some of these complications were due to metabolites of Levodopa, or to modifications in the metabolism of other neurotransmitters by Levodopa, it was natural to turn to analogues of dopamine, in the hope that their direct agonist action upon dopamine receptors would avoid the above problems. The first analogue tried, apomorphine, proved to be effective (Schwab et al., 1951), but unfortunately its oral use in humans produced a pre-renal azotemia which caused the abandonment of the drug (Cotzias et al., 1970, Duby et al., 1972). A derivative, $\mathrm{N}$-propylnoraporphine (Cotzias et al., 1976) was also effective, but its therapeutic effect lasted only a few weeks except when combined with $\alpha$-methyldopa hydrazine plus Levodopa. Other analogues fared less well. This was especially the case for Piribedil (ET-495, Trivastal $R$ ) and Lergotryle ${ }^{R}$, although the latter appeared to be free of dyskinesia producing effects (Calne et al., 1975). The latest compound to be tried is an ergot derivative, also useful in the control of galactorhea and now of acromegaly: CB-154 (Bromocryptine) (Calne et al., 1974). Like all the other dopamine analogues, CB-154 is paradoxically most effective against tremor, and only secondarily, at much higher doses, upon akinesia. It does produce a significant improvement in the motor performance of Parkinsonian patients, but is not free of side effects. Nausea, vomiting, abnormal involuntary movements and even "on/off' phenomena attest to the central dopaminergic action of this drug, but also indicate that these manifestations could not have previously been due to Levodopa metabolites other than dopamine. In my opinion, most of these analogues will be useful tools for the physiological study and dissection of Parkinsonism and of its symptoms, but not many will replace Levodopa as a drug. Meanwhile new analogues are still being developed and tested, both in animals and in humans. It is interesting to note that the use of variable test-models have recently revealed that all analogues do not behave in identical fashion, leading to the conclusions that they act either on different dopamine receptors or that they are not as specific to dopamine as was previously thought.

Another way to increase brain dopamine levels has recently been proposed. It is based on the studies of Youdim and collaborators (1972) showing that there are two forms of monoamine oxidase (MAO) in the brain: MAO-A which mainly deaminates serotonin, noradrenalin, octopamine, tyramine and dopamine; and MAO-B which concentrates on 
phenylethylamine, tyramine and dopamine. Chlorgyline and Harmaline are specific inhibitors of MAO-A, while Deprenil ${ }^{\mathrm{R}}(\mathrm{N}-2-$ dimethyl-N-propynl-2-phenylethylamine-hydrochloride) inhibits MAO-B. Deprenil ${ }^{R}$ has recently been tried in Parkinsonian patients (Birkmayer et al., 1975). Alone it was not very successful, but in combination with Levodopa and a dopa-decarboxylase inhibitor it appears to offer promise.

Finally, we should report on a completely new approach to the treatment of Parkinsonism which stems from two independent observations: First, it was shown by Cotzias and co-workers (1967) that M.S.H. (melanocyte-stimulating hormone) injections produced a rapid worsening of the existing Parkinsonian symptomatology; secondly, Shuster and associates (1973) demonstrated the presence of elevated plasma MSH levels in Parkinsonian patients. Nair et al (1971) synthesized a tripeptide Lprolyl-L-leucyl-glycine amide (PLG) which proved to have M.I.F. (MSH-release inhibitory factor) activity. Subsequently Plotnikoff et al (1971) and Plotnikoff and Kastin (1974) showed that this peptide could potentiate the actions of Levodopa and of oxotremorine in animals. Soon PLG (MIF-I) was tried in humans and shown to have some antiparkinson activity (Kastin and Barbeau, 1972; Chase et al., 1974; Fischer et al., 1974; Barbeau, Roy and Kastin, 1976) especially by the intravenous route. Barbeau (1975c) recently reported a spectacular potentiation of the response to Levodopa in humans. He also reviewed all the studies leading to this result during the 5 th International Symposium on Parkinson's Disease in Vienna (September 1975). There is no doubt that this approach deserves a more thorough investigation, since it constitutes one of the first demonstrations of the behavioural action of hypothalamic polypeptides upon the brain.

As it should be obvious to all neurologists, further progress in the therapy of Parkinson's disease will require new imaginative approaches, and particularly a solution to the problem of the etiology of this illness. This solution is probably still far away, but two new facts should help in future studies: First, the demonstration that Parkinsonian platelets also exhibit a dopamine uptake defect (Barbeau et al., 1975), thus providing an easily accessible model; and secondly, the emerging importance of superoxide radicals as a factor in the cell damage of ageing, and the fact that dopamine can serve as a trapping agent for these radicals. G. Cohen (1975, unpublished observations) has postulated that the gradually decreasing striatal levels of dopamine in Parkinsons' disease and with age (Barbeau, 1973) contributes to the accelerated process of cell ageing. These recent findings are, of course, preliminary, but should be pursued further. They indicate that, in Parkinson's disease, there may be accelerated ageing of specific catecholaminergic (pigmented) neuronal systems. We recently hypothesized (Barbeau, A.R.N.M.D. Meeting, December, 1975) that a deficit in the specialized "A.P.U.D." cells in the hypothalamus (cells that produce peptides and amines and originate from the neural crest) may be at the origin of the disease.

\section{ACKNOWLEDGEMENTS}

The author's own studies reported in this review have been supported in part by grants from the Medical Research Council of Canada (MT-4938), the W. Garfield Weston Foundation and the United Parkinson Foundation. Collaborators to these studies have been indicated as co-authors in the articles cited.

\section{REFERENCES}

BARBEAU, A. (1961). Biochemistry of Parkinson's disease. Excerpta Medica. I.C.S. 38: 152-153.

BARBEAU, A. (1969). L-DOPA therapy in Parkinson's disease: A critical review of nine years' experience. Can. Med. Ass. J. 101: 791-800.

BARBEAU, A. (1973). Aging and the extrapyramidal system. J. Amer. Geriat. Soc. 21: 145-149, 1973.

BARBEAU, A. (1975). Résultats à long terme de la L-Dopa dans la maladie de Parkinson. Union Méd. Canada 104: 3238. 1975.

BARBEAU, A. (1975). Long-term assessment of Levodopa therapy in Parkinson's disease. Can. Med. Ass. J. 112: 1379-1380.
BARBEAU, A. (1975). Potentiation of Levodopa effect by intravenous L-prolyl-L-leucyl-glycine amide in man. Lancet 2: 683-684.

BARBEAU, A. (1976). 6 years of high level Levodopa therapy in severely akinetic parkinsonian patients. Arch. Neurol., in press.

BARBEAU, A., CAMPANELLA, G.. BUTTERWORTH, R. F. and YAMADA. K. (1975). Uptake and efflux of ${ }^{14} \mathrm{C}$-dopamine in platelets: Evidence for a generalized defect in Parkinson's disease. Neurology 25: 1-9.

BARBEAU, A. and McDOWELL, F. H. (Eds.) (1970). L-DOPA and Parkinsonism. F. A. Davis Ltd., Philadelphia, pp. 1-433.

BARBEAU, A. and ROY, M. (1976). Sixyear results of treatment with Levodopa plus benzerazide in Parkinson's disease. Neurology, in press.

BARBEAU, A., ROY, M. and KASTIN, A. J. (1976). Double-blind evaluation of oral L-prolyl-L-leucyl-glycine amide in Parkinson's disease. Can. Med. Ass. J. 114: 120-122.

BIRKMAYER, W. and HORNYKIEWICZ, O. (1961). Der L-3,4-dioxyphenylatanin (Dopa) - Effekt bei der Parkinson akinese. Wien. Klin. Wschr. 73: 787-795. 1961.

BIRKMAYER, W. and MENTASTI, M (1967). Weitere experimentelle untersuchungen "ber den catecholaminstoffwechsel bei extrapyramidalen erkrankungen (Parkinson und chorea syndrom). Arch. Psychiatr. Nervenkr. 210: 29-35.

BIRKMAYER, W., RIEDERER, P.. YOUDIM, M. B. H. and LINAUER, W. (1975). The potentiation of the anti-ikinetic effect after L-DOPA treatment by an inhibitor of MAO-B, deprenil. J. Neural Transmission 36: 303-326.

BLASHKO, H. and MUSCHOLL, E. (Editors) (1972). Catecholamines Springer-Verlag, Berlin, pp. 1-1054.

CALNE, D. B. (Editor) (1973). Progress in the treatment of Parkinsonism, Advances in Neurology, Vol. 3. Raven Press. New York. pp. 1-326.

CALNE, D. B., CHASE, T. N. and BARBEAU, A. (Editors) (1975). Dopaminergic Mechanisms, Advances in Neurology. Vol. 9, Raven Press, New York, pp. 1-452.

CALNE, D. B., TEYCHENNE, P. F. and LEIGH. P. N. (1974). Treatment of Parkinsonism with Bromocriptine. Lancet 2: 1355-1356.

CHASE, T. N., WOODS. A. C., LIPTON, M. A. and MORRIS, C. E. (1974). Hypothalamic releasing factors and Parkinson's disease. Arch. Neurol. 31: 55-56.

Cotzias, G. C., Papavasiliou. P. S. FEHLING, C.. KAUFMAN, B. and MENA. I. (1970). Similarities between neurologic effects of L-DOPA and apomorphine. New Engl. J. Med. 282: 31-33.

Cotzias. G. C.. PAPaVasiliou, P. S. TOLOSA, E. S.. MENDEZ, J. S. and BELL-MIDURA, M. (1976). Treatment of 
Parkinson's disease with aporphines Possible role of growth hormone, New Engl. J. Med. 294: 567-572.

COTZIAS, G. C., VAN WOERT, M. H. and SCHIFFER, L. (1967). Aromatic amino acids and modifications of Parkinsonism. New Engl. J. Med. 276: 374-379.

DE AJURIAGUERRA (Editor) (1971). Monoamines, noyaux gris centraux et syndrome de Parkinson. Masson et Cie, Paris, pp. 1-585.

DUBY, S. E., COTZIAS, G. C., PAPAVASILIOU, P. S. (1972). Injected apomorphine and orally administered Levodopa in Parkinsonism. Arch. Neurol. 27: 474-480.

FISCHER, P. A., SCHNEIDER, E. JACOBI, P. and MAXION, H. (1974). Effect of melanocyte-stimulating hormonerelease inhibiting factor (MIF) in Parkinson's syndrom. Europ. Neurol. 12: 360-368.

FUXE, K., HOKFELT, T. and UNGERSTEDT, U. (1970). Morphological and functional aspects of central monoamine neurons. Internat. Rev. Neurobiol. 13: 93-126, 1970.

HOEHN, M. M. and YAHR, M. D. (1967). Parkinsonism: Onset, progression and mortality. Neurology 17: 427-435.
KASTIN, A. J. and BARBEAU, A. (1972). Preliminary clinical studies with L-prolyl-L-leucyl-glycine amide in Parkinson's disease. Can. Med. Ass. J. 107: 1079-1081.

LIVETT, B. G. (1973). Histochemical visualization of peripheral and central adrenergic neurones. $\mathrm{Br}$. Med. Bull. 29: 93-99.

MARKHAM, C. H., TRECIOKAS, L. J. and DIAMOND, S. G. (1974). Parkinson's disease and Levodopa-a five year follow-up and review. West. J. Med. 121: 188-206.

MARSDEN, C. D. and PARKES, J. D. (1976). "On-off" effects in patients with Parkinson's disease on chronic Levodopa therapy. Lancet 1: 292-296.

McDOWELL, F. H. and BARBEAU, A. (Editors) (1974). Second CanadianAmerican Conference on Parkinson's Disease, Advances in Neurology Vol. 5, Raven Press, New York. pp. 1-512.

NAIR, R. M. G., KASTIN, A. J. anc SCHALLY, A. V. (1971). Isolation and structure of hypothalamic MSH releaseinhibiting-hormone. Biochem. Biophys. Res. Commun. 43: 1376-1381.

PLOTNIKOFF, N. P. and KASTIN, A. J. (1974). Oxotremorine antagonism by prolyl-leucyl-glycine amide administered by different routes and with several an- ticholinergics. Pharmacol. Biochem. Behav. 2: 417-424.

PLOTNIKOFF, N. P., KASTIN, A. J., ANDERSON, M: S. and SCHALLY, A. V. (1971). Dopa potentiation by a hypothalamic factor, MSH releaseinhibiting hormone (MIF). Life Sci. 10: 1279-1283.

SCHWAB, R. S., AMADOR, L. V. and LETTVIN, J. Y. (1951). Apomorphine in Parkinson's disease. Trans. Am. Neurol. Assoc. 76: 251-253.

SHUSTER, S., BURTON, J. L., THODY, A. J., PLUMmER, N., GOOLAMALI, S. K. and BATES, D. (1973). Melanocytestimulating hormone and parkinsonism. Lancet 1: 463-465.

THIERRY, A. M., BLANC, G., SOBEL, A., STINUS, L. and GLOWINSKI, J. (1973). Dopaminergic terminals in the rat cortex. Science 182: 499-501.

YAHR, M. D. (1973). Treatment of Parkinsonism - The role of dopa decarboxylase inhibitors. Advances in Neurology, Vol. 2, Raven Press, New York, pp. 1-303.

YOUDIM, M. B. H., COLLINS, G. G. S., SANDLER, M., BEVAN-JONES, A. B., PARE, C. M. B. and NICHOLSON. W. J. (1972). Human brain monoamine oxidase, multiple forms and selective inhibitors. Nature 236: 225-228. 